\title{
First Report of Congenital Neospora Caninum Encephalomyelitis in Two Newborn Calves in the Argentinean Pampas
}

\author{
Juan Francisco Micheloud ${ }^{1 *}$, Dadin Prando Moore ${ }^{2}$, Ana Maria Canal ${ }^{3}$, Lilian Lischinsky ${ }^{1}$, Yanina Paola Hecker ${ }^{2}$, German Jose Canton ${ }^{1}$, Ernesto Odriozola ${ }^{1}$, \\ Anselmo Carlos Odeon ${ }^{1}$ and Carlos Manuel Campero ${ }^{1}$ \\ ${ }^{1}$ National Institute of Agrarian Technology, Argentina \\ ${ }^{2}$ National Research Council, CP C1033AAJ, Buenos Aires, Argentina \\ ${ }^{3}$ School of Veterinary Sciences, National University of Litoral, Santa Fe, Argentina \\ "Corresponding author: Juan Francisco Micheloud, 1National Institute of Agrarian Technology, Argentina, Tel: (0387) 490 2214/490 2224; E-mail: \\ micheloud.juan@inta.gob.ar
}

Rec date: Jul 15, 2015; Acc date: Sep 15, 2015; Pub date: Sep 17, 2015

Copyright: (C 2015 Micheloud JF, et al. This is an open-access article distributed under the terms of the Creative Commons Attribution License, which permits unrestricted use, distribution, and reproduction in any medium, provided the original author and source are credited.

\begin{abstract}
Bovine neosporosis is a parasitic disease of major concern in cattle industry worldwide. Although abortion is the more frequent clinical presentation, sporadic congenital clinical bovine neosporosis has been scarcely reported in newborn calves. Neospora caninum encephalomyelitis was diagnosed in two of 314 newborn calves submitted for necropsy and laboratory analysis between 2000 and 2014. The two new born calves had limb dysfunction, loss of conscious proprioception and ataxia. Protozoal multifocal nonsuppurative encephalomyelitis was observed and diagnosis was confirmed using serology, immunohistochemistry and PCR. This is the first report of clinical congenital neosporosis in calves from Argentina.
\end{abstract}

Keywords: Congenital neosporosis; Encephalomyelitis; Newborn calves

\section{Introduction}

Neospora caninum is an apicomplexan protozoan parasite causing bovine abortion worldwide [1] and its global economic impact has been estimated in over 1 billion dollars [2]. Transplacental transmission occurs efficiently during bovine pregnancy in a chronically $N$. caninum-infected dam [3]. Also, bovine postnatal infection occurs by consuming food and/or water contaminated with $N$. caninum oocysts shed in the feces of the definitive hosts [4]. The abortion or birth of a congenital infected calf is influenced by the stage of gestation, the immunity in the dam, the placenta and the fetus [5-8]. In spite of the main presentation of the disease in cattle is the abortion [9], other neurological signs including limb dysfunction (flexion or hyperextension), loss of conscious proprioception and ataxia have been also described in newborn or young calves in Belgium [9], Canada $[10,11]$, England [12,13], Italy [14], Japan [15] and United States $[5,12,16-18]$.

Neospora abortions in the Argentinean pampas, have been recently estimated [19]. The total dairy and beef cattle population at risk of abortion was $1,771,326$ and $9,726,684$ heads, respectively. In dairy cattle, there may be an $8 \%$ risk of experiencing abortion and $16.5 \%$ of them could be due to $N$. caninum. In beef cattle, the overall risk of abortion was estimated to be $4.5 \%$, whereas $6.7 \%$ could be specifically due to $N$. caninum.

Clinical $N$. caninum encephalomyelitis in newborn calves is sporadically reported [1]. Nevertheless, calf mortality remains undetermined in more of $50 \%$ of cases [20-22]. The aim of this report is to describe two cases of clinical neosporosis in newborn calves from two different herds located at the Argentinean pampas, one of the most important livestock production regions of the world.

\section{Materials and Methods}

Newborn calves ( $n=314$ ) belonging to 297 herds (94 dairy farms and 203 beef farms) at the Argentinean pampas were submitted for necropsy and laboratory analysis between 2000 and 2014. Two of 314 newborn calves had neurological signs and presumptive Neospora infection. The first case report involved a moribund 2 day old Holstein calf, which was submitted alive to the Specialized Veterinary Diagnostic Service at the National Institute of Agrarian Technology, Balcarce, Argentina in August 2000. Data regarding to the dairy herd revealed antecedents of endemic neosporosis having a seroprevalence of $16.5 \%$ of 850 Holstein cows and over $10 \%$ of annual abortions. The herd was tuberculosis and brucellosis free. The dairy farm is located at $38^{\circ} 01^{\prime} 82^{\prime \prime} \mathrm{S}, 58^{\circ} 94^{\prime} 85^{\prime \prime} \mathrm{W}$ in Buenos Aires province. The calf was premature (born at 8 months of gestation), stunted, weak, and recumbent and had under corporal weight $(15.5 \mathrm{~kg})$, hypothermia $\left(33.3^{\circ} \mathrm{C}\right)$ and loss of conscious proprioception. Blood was collected from both, the dam and its calf prior to colostrum ingestion. Due to the bad prognosis for the calf, euthanasia and complete necropsy were performed $N$. caninum specific antibodies were assessed by IFAT as previously described [23]. A serological titer of $\geq 1: 200$ was selected as cut-off point.

The second case report occurred in Santo Domingo, Santa Fe province at $31^{\circ} 07^{\prime} 00^{\prime \prime} \mathrm{S} 60^{\circ} 53^{\prime} 00^{\prime \prime} \mathrm{W}$ in July 2012 . A HolsteinxHereford calf was born with $51 \mathrm{~kg}$ but ataxia and limb dysfunction were observed. The calf ingested colostrum and remained alive for 10 days with careful assistance of the farmer. After death, the specimen was submitted to the Department of Basic Pathology, School of Veterinary Sciences, National University of Litoral, Santa Fe, Argentina, where necropsy took place. Reproductive failure was mentioned describing 7 abortions within a period of 3 months in a dual purpose herd of 37 Holstein cows. Also, the anamnesis revealed a previous diagnosis of Bovine Viral Diarrhea virus (BVDv) infections associated to malformations in the herd. $N$. caninum specific antibodies were 
assessed by IFAT in sera from the aborted cows and the dam with the calf having neurological signs $(\mathrm{n}=8)$. The IFAT was used having the same criteria as previously mentioned.

Diagnosis for different microorganisms was performed by various laboratory methods as described by Campero et al. [24]. Briefly, abomasal content, lung and cerebrospinal liquid were cultured on blood and MacConkey's agar at $37^{\circ} \mathrm{C}$ in $7.5 \% \mathrm{CO}_{2}$ for $48 \mathrm{hr}$. Spleen was by inoculating a $10 \%$ tissue homogenate onto cultures of Madin Darby bovine kidney cells. After 4 blind passages, the cultures were tested for BVDv and Bovine Herpesvirus antigens by an indirect fluorescent antibody procedure with a commercially available polyclonal antibody (American Bio-Research, Sevierville, Tn, USA). No attempt was made to isolate neither Mycoplasma sp. nor Chlamydia sp. Fresh kidney impression smears were examined by direct fluorescent antibody test for Leptospira sp.

Tissue samples from multiple organs including brain and cervical, dorsal and lumbar spinal cord were fixed in $10 \%$ neutral buffered formalin, embedded in paraffin, and stained with hematoxylin and eosin $(\mathrm{H} \& \mathrm{E})$ for routine histologic examination. All tissues with microscopic lesions compatible with those produced by apicomplexan protozoan (nonsuppurative meningoencephalitis, myocarditis, hepatitis and miositis) were processed by IHC. IHC was performed using a method of Avidin Biotin Complex (Vector, Peroxidase Elite ABC PK-601) for $N$. caninum $[24,25]$. The primary antibody was antiN. caninum hyperimmune polyclonal rabbit serum (kindly provided by Dr. M. Anderson, UC Davis, USA) diluted 1:200. Immunostaining was visualized with amino-ethylcarbazol substrate (Dako Inc.), and sections were counterstained with Mayer's hematoxylin (Sigma Diagnostics, St. Louis, Mo.) and examined microscopically. Positive control tissue consisted of formalin-fixed brain tissue from mice experimentally inoculated with the NC-1 strain of $N$. caninum. Negative controls consisted of replacement of the primary antibody with a similar dilution of normal rabbit serum.

DNA was extracted from formalin-fixed paraffin embedded tissues with Neospora-compatible lesions as previously described by Moore et al. [26]. Genomic DNA from formalin-fixed paraffin embedded tissues was extracted using a commercially available kit (Qiagen, USA) according to manufacturer's instructions. In order to exclude the possibility of false-negative PCR results due to poor-quality DNA or the presence of nonspecific PCR inhibitors in the clinical tissue samples, conventional PCR for the amplification of $28 \mathrm{~S}$ rRNA host gene was performed using the primers described by CollantesFernandez et al. [27]. Neospora DNA was detected by a nested-PCR on the internal transcribed spacer (ITS1) region with 4 oligonucleotides as described by Buxton et al. [28]. In addition, a single-tube nested-PCR assay was performed to detect $T$. gondii DNA as described by Hurtado et al. [29]. Positive (purified N. caninum or T. gondii tachyzoite DNA) and negative controls (DNA from normal bovine brain, paraffin control, and double-distilled water) were included in each PCR Secondary amplification products were visualized by $1.8 \%$ agarose gel electrophoresis and ethidium bromide staining under UV light.

\section{Results}

Gross lesions were not observed in the first calf but an ulcer in the abomasum and severe hemorrhagic duodenitis were described in the second calf.

In first case report, the titer of specific IgG were 1:400 and 1:800 in the dam and its premature calf. In the second case, 6 of 8 cows, including the dam of the calf having neurological signs, had specific antibodies $\geq 1: 200$.
Microscopically, both calves had multifocal areas of liquefactive necrosis, focal areas of gliosis, and diffuse perivascular cuffing (Figure 1a). Areas of hypercellularity due to mild inflammatory mononuclear cell infiltration were also seen throughout the meninges. Numerous gitter cells, prominent capillaries due proliferation and endothelial swelling were also observed in areas of necrosis and cavitation. Neuropil was spongiotic due to edema and degenerating axons. The inflammatory cell infiltrate was composed of plasma cells, lymphocytes and macrophages. These microscopical lesions were found mostly in the brain cortex and cerebellum in the calf from the first case. In contrast, the cervical section of the spine cord was more severely affected in the calf from the second case.

Few thick walled $N$. caninum-like tissue cysts were found (Figure 1b). Necrotic and degenerate myocytes accompanied by infiltrates of macrophages and lymphocytes were also evident in skeletal muscle in both calves. Other findings were limited to the gastrointestinal tract were observed in the second calf. Those included mucosal erosion and ulceration in the abomasum and leukocytic infiltrate, edema and fibrin deposition in the lamina propria of the duodenitis. Tachyzoites and tissue cysts in the brain of both calves reacted positively to anti- $N$. caninum sera (Figures 1c and 1d). Bright bands of $249 \mathrm{pb}$ consistent with $N$. caninum were amplified in the brains and spinal cord from both calves. On the contrary, the PCR for T. gondii did not amplify any product. No other microorganisms were identified by the methods and techniques performed in the present work.

Other causes of perinatal death were determined in $32 \%$ of the 314 submitted specimens (data no shown). Most cases were diagnosed as bovine enteric colibacillosis and fatal diarrhea due to rotavirus (unpublished data). In the remaining 68\%, the etiology was not determined by the standard laboratory procedures used in this study.

\section{Discussion}

Bovine neosporosis was identified as cause of abortion in the late 80's [30]. Knowledge about diagnosis, cycle of parasite and epidemiology progressed quickly applying most methods and techniques previously used in toxoplasmosis [1]. Currently, most veterinarians consider $N$. caninum as differential diagnosis in bovine abortion but few of them are aware about congenital bovine neosporosis in neonates. Definitively congenital bovine neosporosis must be considered in the differential diagnosis in calves having neurological signs. Moreover, rapid and efficient diagnosis should be performed in order to identify the presentation of the disease and to apply adequate sanitary actions. In the present study, the diagnosis was based on exclusion of other etiologies, and associated $N$. caninum with lesions using several diagnostic methods. Promising results by using toltrazuril and its derivative ponazuril have been reviewed to control bovine neosporosis [1]. On the hand, dogs having neurological disorders recovered properly when receiving clindamycin, potentiated sulphonamides and/or pyrimethamine [31]. Whether these drugs are equally efficient in cases congenital bovine neosporosis remains to be determined.

The etiology of bovine neonatal mortality is not fully explained [22] Based on data from 1994 to 2007 over 10 million calves are delivered each year in the Argentinean pampas but abortions due to $N$. caninum in dairy and beef cattle were estimated to be 23,382 and 29,326, respectively [19]. Neonatal mortality associated to Neospora-infections may occur more frequently than recorded in our Labs from 2000 to 2014). Approximately, 35 million dollars due $N$. caninum abortions have been estimated to be lost every year by the cattle industry in the 
Citation: Micheloud JF, Moore DP, Canal AM, Lischinsky L, Hecker YP, et al. (2015) First Report of Congenital Neospora Caninum

Argentina [19]. This value could be underestimated if not neonatal mortality by $N$. caninum is not considered.

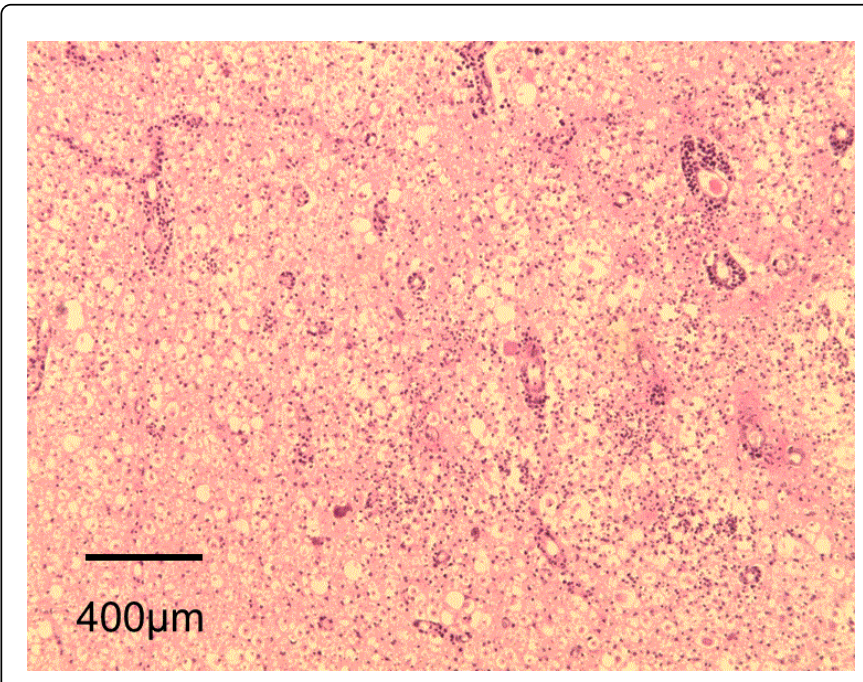

Figure 1a: Cervical spine cord from calf \#2 suffering congenital neosporosis. H\&E stain. Note the numerous inflammatory mononuclear cells, gliosis, and extensive liquefaction necrosis and perivascular leukocytic infiltration.

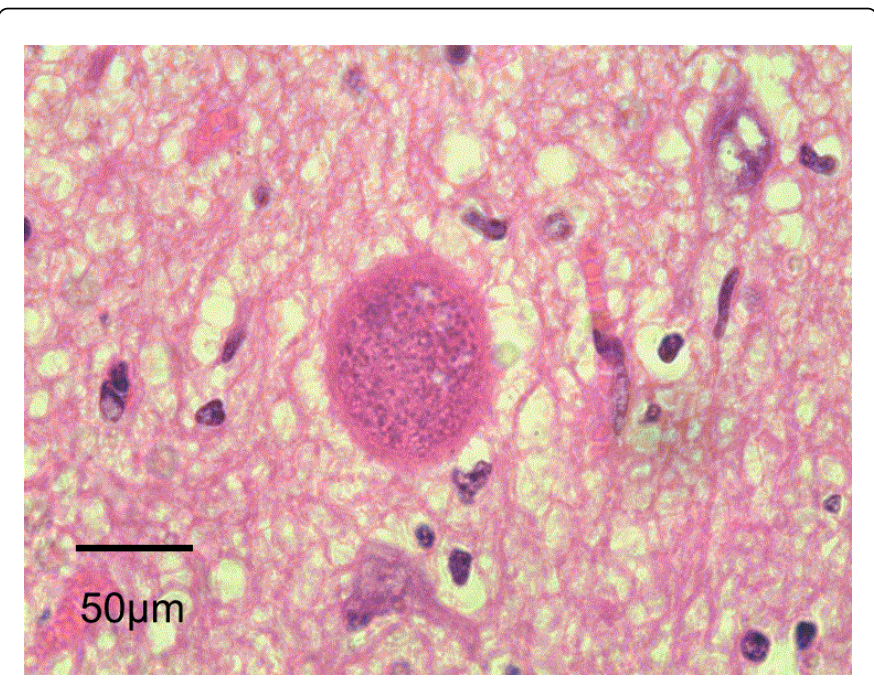

Figure 1b: Brain from calf\#1, H\&E stain. Note the slightly oval, strongly eosinophilic, protozoal cysts, approximately $50 \times 60 \mathrm{um}$ in size.

\section{Acknowledgement}

We would like to express our thanks for the support of veterinary practitioners and the assistance provided by the veterinarians of the Residence in Animal Health Program and laboratory technicians of the Animal Health Group, INTA Balcarce. This work was funded by a Research Grants from MINCYT, PICT-2011-1179 and INTA PNSA-1115053.

\section{Conflict of Interest Statement}

The authors declare that they have no conflict of interest.

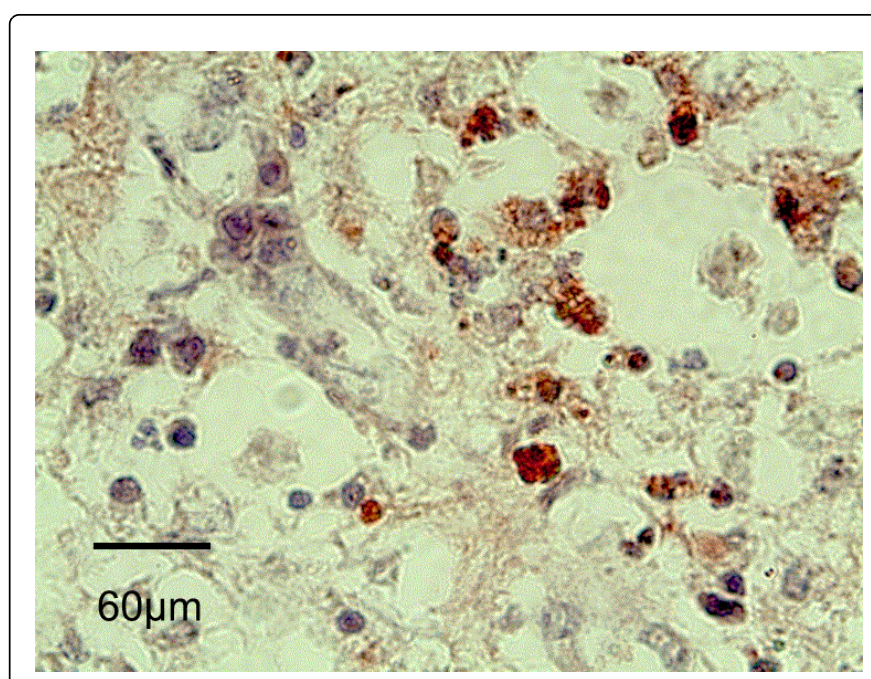

Figure 1c: $N$. caninum tachyzoites stained by IHC in the brain from calf \#2.

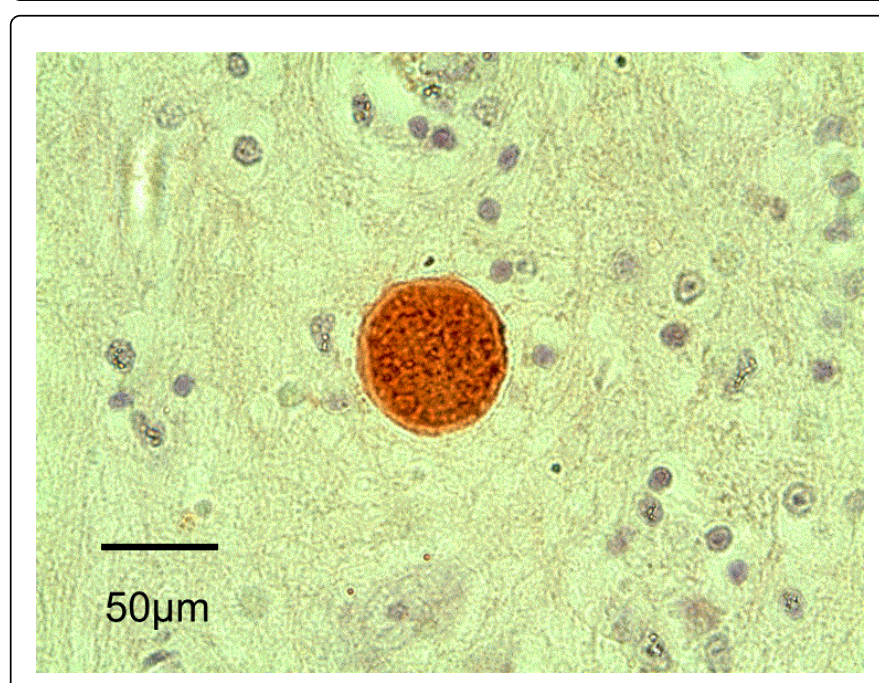

Figure 1d: Brain from calf \#1: Note the protozoal cyst stained by IHC.

\section{References}

1. Dubey JP, Schares G, Ortega-Mora LM (2007) Epidemiology and control of neosporosis and Neospora caninum. Clin Microbiol Rev 20: 323-367.

2. Reichel MP, Alejandra Ayanegui-Alcérreca M, Gondim LF, Ellis JT (2013) What is the global economic impact of Neospora caninum in cattle - the billion dollar question. Int J Parasitol 43: 133-142.

3. Anderson ML, Reynolds JP, Rowe JD, Sverlow KW, Packham AE, et al. (1997) Evidence of vertical transmission of Neospora sp infection in dairy cattle. J Am Vet Med Assoc 210: 1169-1172.

4. Trees AJ, McAllister MM, Guy CS, McGarry JW, Smith RF, et al. (2002) Neospora caninum: oocyst challenge of pregnant cows. Vet Parasitol 109: $147-154$

5. Barr BC, Conrad PA, Breitmeyer R, Sverlow K, Anderson ML, et al. (1993) Congenital Neospora infection in calves born from cows that had previously aborted Neospora-infected fetuses: four cases (1990-1992). J Am Vet Med Assoc 202: 113-117.

6. Bartley PM, Katzer F, Rocchi MS, Maley SW, Benavides J, et al. (2013) Development of maternal and foetal immune responses in cattle 
Citation: Micheloud JF, Moore DP, Canal AM, Lischinsky L, Hecker YP, et al. (2015) First Report of Congenital Neospora Caninum Encephalomyelitis in Two Newborn Calves in the Argentinean Pampas. J Veterinar Sci Technol 6: 251. doi:10.4172/2157-7579.1000251

Page 4 of 4

following experimental challenge with Neospora caninum at day 210 of gestation. Vet Res 44-91.

7. Cantón GJ, Katzer F, Maley SW, Bartley PM, Benavides-Silván J, et al. (2014) Inflammatory infiltration into placentas of Neospora caninum challenged cattle correlates with clinical outcome of pregnancy. Vet Res 45: 11 .

8. Williams DJ, Guy CS, McGarry JW, Guy F, Tasker L, et al. (2000) Neospora caninum-associated abortion in cattle: the time of experimentally-induced parasitaemia during gestation determines foetal survival. Parasitol 121: 347-358.

9. De Meerschman F, Focant C, Detry J, Rettigner C, Cassart D, et al. (2005) Clinical, pathological and diagnostic aspects of congenital neosporosis in a series of naturally infected calves. Vet Rec 157: 115-118.

10. Bryan LA, Gajadhar AA, Dubey JP, Haines DM (1994) Bovine neonatal encephalomyelitis associated with a Neospora sp. protozoan. Can Vet J 35: 111-113.

11. Illanes O, Moore A, Pringle J, Saindon A (1994) Neospora-induced congenital myelitis and polyradiculoneuritis in a one-month-old Holstein calf. Can Vet J 35: 653-654.

12. Dubey JP (1989) Congenital neosporosis in a calf. Vet Rec 125: 486.

13. O'Toole D, Jeffrey M (1987) Congenital sporozoan encephalomyelitis in a calf. Vet Rec 121: 563-566.

14. Magnino S, Vigo PG, Fabbi M, Colombo M, Bandi C, et al. (1999) Isolation of a bovine Neospora from a newborn calf in Italy. Vet Rec 144: 456.

15. Ogino H, Watanabe E, Watanabe S, Agawa H, Narita M, et al. (1992) Neosporosis in the aborted fetus and newborn calf. J Comp Pathol 107: 231-237.

16. Barr BC, Conrad PA, Dubey JP, Anderson ML (1991) Neospora-like encephalomyelitis in a calf: pathology, ultrastructure, and immunoreactivity. J Vet Diagn Invest 3: 39-46.

17. Dubey JP, Janovitz EB, Skowronek AJ (1992) Clinical neosporosis in a 4week-old Hereford calf. Vet Parasitol 43: 137-141.

18. Parish SM, Maag-Miller L, Besser TE, Weidner JP, McElwain T, et al (1987) Myelitis associated with protozoal infection in newborn calves. J Am Vet Med Assoc 191: 1599-1600.
19. Moore D, Reichel M, Spath E, Campero C (2013) Neospora caninum causes severe economic losses in cattle in the humid pampa region of Argentina. Trop Anim Health Prod 45: 1237-1241.

20. Berglund B, Steinbock L, Elvander M (2003) Causes of stillbirth and time of death in Swedish Holstein calves examined post mortem. Acta Vet Scand 44: 111-120.

21. Khan A, Khan M (1991). Aetiopatology of neonatal calf mortality. J Islamic Ac Sci 4:159-165.

22. Morrell EL, Moore DP, Odeón AC, Poso MA, Odriozola E, et al. (2008) Retrospective study of bovine neonatal mortality: cases reported from INTA Balcarce, Argentina. Rev Argent Microbiol 40: 151-157.

23. Moore DP, Campero CM, Odeón AC, Posso MA, Cano D, et al. (2002) Seroepidemiology of beef and dairy herds and fetal study of Neospora caninum in Argentina. Vet Parasitol 107: 303-316.

24. Campero CM, Moore DP, Odeón AC, Cipolla AL, Odriozola E (2003) Aetiology of bovine abortion in Argentina. Vet Res Commun 27: 359-369.

25. Lindsay DS, Dubey JP (1989) Neospora caninum (Protozoa: apicomplexa) infections in mice. J Parasitol 75: 772-779.

26. Moore DP, Regidor-Cerrillo J, Morrell E, Poso MA, Cano DB, et al. (2008) The role of Neospora caninum and Toxoplasma gondii in spontaneous bovine abortion in Argentina. Vet Parasitol 156: 163-167.

27. Collantes-Fernández E, Zaballos A, Alvarez-García G, Ortega-Mora LM (2002) Quantitative detection of Neospora caninum in bovine aborted fetuses and experimentally infected mice by real-time PCR. J Clin Microbiol 40: 1194-1198.

28. Buxton D, Maley SW, Wright S, Thomson KM, Rae AG, et al. (1998) The pathogenesis of experimental neosporosis in pregnant sheep. J Comp Pathol 118: 267-279.

29. Hurtado A, Aduriz G, Moreno B, Barandika J, García-Pérez AL (2001) Single tube nested PCR for the detection of Toxoplasma gondii in fetal tissues from naturally aborted ewes. Vet Parasitol 102: 17-27.

30. Thilsted JP, Dubey JP (1989) Neosporosis-like abortions in a herd of dairy cattle. J Vet Diagn Invest 1: 205-209.

31. Barber JS, Trees AJ (1996) Clinical aspects of 27 cases of neosporosis in dogs. Vet Rec 139: 439-443. 